diversity as a species approaches extinction, he says, "you could then take these hard-core sequencing data to political decision-makers and say, 'this absolutely has to stop'".

If the case of the Tasmanian devil is anything to go by, though, politicians may not yet be ready to listen to geneticists. Schuster and workshop co-organizer Webb Miller, also of Penn State University, teamed up with Vanessa Hayes of the Children's Cancer Institute Australia in Sydney in late 2007 to sequence the genome of the Tasmanian devil, a species on the verge of extinction due to a communicable cancer.

The ultimate goal of identifying the genetic basis for resistance to the cancer (which some animals seem to show) is still some way off, but the researchers have already identified 50 gene markers that allow them to describe the genetic make-up of individual devils. As yet, however, there is no sign that the Tasmanian authorities are prepared to incorporate the maintenance of the genetic diversity that these markers can measure into the conservation plan for the species.

An IUCN representative, who did not attend the workshop, was uncertain whether genomic data would be of widespread benefit for conservation. "The study of species' genomes could prove valuable, but probably only in a very limited number of cases," says Jean-Christophe Vié, deputy head of the IUCN species programme in Gland, Switzerland. "For example, if it could help us solve the amphibian extinction crisis by explaining what makes so many amphibians vulnerable to the chytrid fungus, that would be a major contribution."

Curators at the meeting broadly welcomed the "red and dead" idea. "I don't think there will be any difficulty convincing museum people of having their specimens used for this work," says Richard Sabin, curator of mammals at the Natural History Museum in London.

But he points out that extracting DNA requires removing a sliver of tissue from the relevant museum specimen - not something curators take lightly - and the record for samples taken for genetic analysis is not good. Between 2000 and 2007, for example, Sabin says his museum granted 70 requests to sample mammal specimens, resulting in 674 tissue samples being taken. Only two gene sequences from all of these samples made it into the public gene database, GenBank. The reasons for such a low hit rate remain unclear, although failure to extract DNA might be one. But "it is critical for them to report back to us, even if they get nothing from a sample", says Sabin, who has toughened up the museum's policy to make sure this happens.

Henry Nicholls

\title{
Bomb spurs research rally
}

On 7 March David Jentsch, a neuroscientist at the University of California, Los Angeles (UCLA), had his car firebombed outside his house by animal extremists. In response, he formed the group UCLA Pro-Test to oppose such extremism and advocate continued research on animals. The group will hold its first rally on 22 April on the university's campus.

\section{What sort of research do you do?}

I study the neuroscience of mental disorders, with a basic scientific lab approach. Schizophrenia is a major study area. We study how genes in normal animals influence brain function. And we study how potential treatments work. Every project I do in an animal is connected with a human clinical question.

\section{How do you use those animals?}

I use rodent and vervet monkey models. We do a lot of work relating genetics to brain function, such as memory and attention. We use invasive procedures or infusions of pharmaceutical drugs. We also use genetic mutation knockouts in rodents. In monkeys, we study genetics and naturally occurring functions. We primarily use noninvasive procedures on monkeys - about $90 \%$ are behaviour and genetics studies.

\section{What happened in the attack?}

It was 4 a.m. on Saturday 7 March. I was awakened by a loud bang; then I heard the car alarm go off. I went to the window and saw my car on fire. I ran outside to try to put it out, using a fire extinguisher and a garden hose. It was impossible. The gas tank had exploded. When the windows started exploding, I got out of there. The fire got into the trees. If this was July in fire season, I don't want to even think about what would have happened. It would have been an enormous fire with many homes threatened. No one was injured.

\section{Did you immediately suspect extremists?} I admit I didn't think of anything else but animal extremists. I am very close to other researchers at UCLA who have been attacked in the past. My immediate reaction was confirmed on Monday 9 March when the North American Animal Liberation Press Office posted a communiqué taking responsibility.

Did you suspect the attack was retaliation for recent US arrests of extremists? It is hard to say. The communiqué explicitly linked the attack to the arrests, saying: 'You hit us; we hit you back harder.' I think they would have come anyway.

How did you come to found UCLA Pro-Test? As I walked the UCLA hallways, students, staff and colleagues would approach me. I realized this was affecting many people. The institution was the real target. Others besides myself were traumatized. I knew the extremists would have demonstrations on 22 April for World Week for Animals in Laboratories. I got the idea to do our own rally - to share experiences of our enterprise. I contacted Tom Holder, the UK Pro-Test founder. Within an hour, he was on board.

\section{What do you hope to achieve?}

The immediate goal is a rally for proresearch and science advocates to demonstrate our common mission to the community at large. We also want to start a process in which we will no longer let them bomb people and be quiet. The people now traumatized are the ones who know they are next. Those people need support. We are creating a university structure to centralize decision-making on this problem.

\section{Do you think you can change the views of extremists?}

I don't think we can. We can have an open and honest discussion with them to explain the place for animal research in society. But they won't change our mind anymore than we can change theirs.

\section{How would you suggest that others confront extremism?}

In the past, we were always responding to events, instead of being proactive. Everyone at the university knows who the likely targets are. Responses came after attacks, when we were in the thick of the problem. Now we are taking advance steps. There are common-sense things any university can do to be ready. I'm now getting calls from other universities about what they should do. Interview by Rex Dalton 